\title{
TRACER STUDY LULUSAN PROGRAM STUDI BIMBINGAN DAN KONSELING UNIVERSITAS NEGERI GORONTALO
}

\author{
Maryam Rahim \\ Prodi Bimbingan dan KonselingUniversitas Negeri Gorontalo \\ E-mail: maryamrahim63@gmail.com \\ Meiske Puluhulawa \\ Prodi Bimbingan dan Konseling, Universitas Negeri Gorontalo \\ E-mail : puluhulawameiske@gmail.com
}

\begin{abstract}
Abstrak
Penelitian ini diharapkan dapat memperbaiki dan meningkatkan kualitas pengelolaan program studi Bimbingan dan Konseling Universitas Negeri Gorontalo berdasarkan informasi yang diperoleh melalui tracer study. Secara khusus, penelitian ini dilakukan untuk memperoleh informasi tentang lulusan, yang meliputi (1) rata-rata masa tunggu lulusan, (2) jenis pekerjaan yang ditekuni, dan (3) tanggapan terhadap pengguna lulusan. Hasil penelitian menunjukkan: (1) rata-rata masa tunggu lulusan adalah 3 bulan; (2) jenis pekerjaan yang ditekuni lulusan terdiri dari 13 kategori yakni (a) Guru BK (PNS) sebanyak 27.31\%; (b) Guru BK (Non PNS) sebanyak 50.00\%; (c) Guru PAUD sebanyak 0.84\%; (d) Guru TK sebanyak 5.04\%; (e) Guru SD sebanyak 4.20\%; (f) Guru SLB sebanyak 0.42\%; (g) Pegawai instansi pemerintah sebanyak 2.52\%; (h) Pegawai perusahaan sebanyak 0.84\%; (i) Dosen sebanyak 1.26\%; (j) Dosen luar biasa sebanyak 1.26\%; (k) Wirausaha sebanyak 3.78\%; (l) Anggota DPR sebanyak 0.42\%; (m) dan lain-lain sebanyak 2.10\%; dan (3) tanggapan pengguna terhadap lulusan, yang menyangkut: (a) integritas (etika dan moral) $=89.60$ (sangat baik); (b) keahlian berdasarkan bidang ilmu (profesionalisme) $=82.92$ (baik); (c) bahasa Inggris = 67.89 (cukup); $(\mathrm{d})$ penggunaan teknologi informasi $=$ 81.71 (baik); (e) komunikasi = 84.06 (baik); (f) kerjasama tim = 85.04 (sangat baik); dan (g) pengembangan diri $=83.83$ (baik).
\end{abstract}

Kata Kunci: Tracer Study, Lulusan, Program Studi Bimbingan dan Konseling

\begin{abstract}
This research is expected to improve and improve the quality of the management of Study Program Guidance and Counseling of State University of Gorontalo based on information obtained through tracer study. Specifically, this study was undertaken to obtain information about graduates, which included (1) the average waiting period for the graduates, (2) the type of work being undertaken, and (3) responses to graduate users. The results showed: (1) the average waiting period of the graduates was 3 months; (2) the type of work occupied by graduates consists of 13 categories, namely (a) Teacher BK (PNS) as much as 27.31\%; (B) Teacher BK (Non PNS) as much as 50.00\%; (C) PAUD teachers as much as $0.84 \%$; (D) Kindergarten teachers as much as $5.04 \%$; (E) elementary school teachers as much as $4.20 \%$; (F) SLB Teachers as much as $0.42 \%$; $(\mathrm{G})$ Employees of government agencies as much as 2.52\%; (H) Company employees 0.84\%; (I) Lecturer as much as 1.26\%; (J) Unusual lecturer as much as 1.26\%; (K) Entrepreneur as much as 3.78\%; (L) Members of the People's Legislative Assembly of 0.42\%; (M) and others as much as $2.10 \%$; And (3) user responses to graduates, which include: (a) integrity (ethics and morals $)=89.60$ (excellent); (B) expertise by field of science (professionalism) $=82.92$ (good); (C) English $=67.89$ (enough); (D) use of information technology = 81.71 (good); (E) communication = $84.06($ good $)$; (F) teamwork = 85.04 (excellent); And $(\mathrm{g})$ self-development $=83.83$ (good).
\end{abstract}

Keywords: Tracer Study, Graduate, Guidance and Counseling Study Program

\section{PENDAHULUAN}

Perguruan tinggi memiliki peranan penting terhadap lulusan sebagai bentuk tanggung jawab secara berkelanjutan bagi out-put yang dihasilkan. Keberhasilan lulusan perguruan tinggi dalam menjalankan perannya di masyarakat menjadi salah satu indikator keberhasilan sebuah perguruan tinggi. Oleh sebab itu perguruan tinggi 
perlu mengikuti terus perkembangan lulusannya untuk memperoleh data tentang kualitas kinerja lulusan, kekurangan apa saja yang masih dimiliki oleh lulusan, di mana mereka bekerja, kapan mereka mulai bekerja dan informasi lainnya.

Tracer study merupakan salah satu kegiatan yang dilakukan perguruan tinggi dalam mengikuti perkembangan lulusan. Tracer study merupakan studi pelacakan jejak lulusan/alumni yang dilakukan sekitar 13 tahun setelah lulus. Tracer study bertujuan untuk mengetahui outcome pendidikan dalam transisi dari dunia pendidikan tinggi ke dunia kerja, output pendidikan yaitu penilaian diri terhadap penguasaan dan pemerolehan kompetensi, proses pendidikan berupa evaluasi proses pembelajaran dan kontribusi pendidikan tinggi terhadap pemerolehan kompetensi, input pendidikan berupa penggalian lebih lanjut terhadap informasi sosiobiografis lulusan (Arwildayanto 2012). Penjelasan ini menunjukkan banyak manfaat yang diperoleh perguruan tinggi melalui kegiatan tracer study. Manfaat itu tidak saja berkaitan dengan penggunaan informasi hasil tracer study bagi lulusan itu sendiri, namun yang penting juga dapat menjadi bahan masukan bagi perbaikan dan peningkatan proses pendidikan yang dilaksanakan di perguruan tinggi, khususnya di tataran jurusan/rogram studi.

Alumni jurusan (selanjutnya disebut program studi) Bimbingan dan Konseling Universitas Negeri Gorontalo dari tahun 2007/2008 sampai tahun 2013/2014 menunjukkan adanya peningkatan sebagai konsekuensi peningkatan animo mahasiswa untuk melanjutkan studi di program studi ini. Alumni program studi Bimbingan dan Konseling sejak tahun akademik 2007/2008 sampai tahun akademik 2013/2014 berjumlah 583 orang,yang tersebar di berbagai daerah Indonesia Timur, seperti Bolaang Mongondow, Luwuk-Banggai, Ampana, Buol, Poso, Kendari, Muna, Bau-Bau, Makassar, Papua, dan daerah kota/kabupaten di provinsi Gorontalo. Peningkatan jumlah mahasiswa yang selanjutnya menjadi alumni, merupakan indikator tingginya kepercayaan masyarakat khususnya masyarakat di kawasan Indonesia Timur terhadap program studi ini. Sebagai upaya menjaga kepercayaan ini, maka perlu dilakukan kegiatan tracer study.

Sejak tahun 2007/2008 sampai tahun 2013/2014 program studi Bimbingan dan Konseling Universitas Negeri Gorontalo telah 1 (satu) kali melaksanakan tracer study, namun hasilnya masih sangat terbatas sebab hanya dapat memperoleh informasi dari sekitar $10 \%$ lulusan/alumni. Oleh sebab itu dipandang perlu untuk melakukan tracer study secara komprehensif agar dapat menjangkau seluruh alumni program studi Bimbingan dan Konseling Universitas Negeri Gorontalo tahun akademik 2007/2008 sampai tahun akademik 2013/2014.

Permasalahan dalam penelitian ini meliputi: (a) Berapa rata-rata masa tunggu lulusan angkatan 2007/2008 sampai angkatan 2013/2014 untuk mendapatkan pekerjaan?, (b) Jenis pekerjaan apa yang ditekuni oleh lulusan angkatan 2007/2008-2013/2014?, dan (c) Bagaimana tanggapan pengguna terhadap lulusan angkatan 2007/2008-2013/2014?. Berdasarkan rumusan masalah, maka tujuan penelitian ini adalah untuk mengetahui: (a) rata-rata masa tunggu lulusan angkatan 2007/2008-2013/2014 untuk mendapatkan pekerjaan?, (b) jenis pekerjaan yang ditekuni oleh lulusan angkatan 2007/2008-2013/2014?, dan (c) tanggapan pengguna terhadap lulusan angkatan 2007/20082013/2014?.

Pendidikan memiliki peran penting dalam mempersiapkan generasi bangsa Indonesia yang mampu hidup dalam dunia yang senantiasa berubah. Hasil akhir yang diharapkan tercapai melalui proses pendidikan adalah individu yang memiliki kemampuan dan keterampilan untuk secara mandiri meningkatkan taraf hidup lahir batin, dan meningkatkan peranannya sebagai pribadi, pegawai, karyawan, warga masyarakat, warga negara dan makhluk Tuhan Yang Maha Esa (Pannen \& Malati 1994). Pendidikan harus mampu melahirkan manusia yang mampu hidup di masyarakat global yang senantiasa mengalami perubahan.

Salah satu persoalan yang dihadapi manusia dalam perubahan ini adalah persoalan kompetisi. Oleh sebab itu pendidikan harus mampu menghasilkan generasi yang kompetitif. Pendidikan nasional harus membangun masyarakat Indonesia masa depan yang mempunyai daya saing, mandiri dan ketahanan hidup. Pendidikan harus mampu menghantarkan masyarakat yang mampu menghadapi masa depan (Kartadinata 2010). Perguruan tinggi turut bertanggungjawab dalam menghasilkan masyarakat Indonesia yang memiliki daya saing, mandiri dan memiliki ketahanan hidup. Dalam menjalankan peran itu perguruan tinggi menghadapi berbagai tantangan.

Salah satu tantangan yang dihadapi perguruan tinggi saat ini adalah kompetisi lulusan antar perguruan tinggi. Semakin banyaknya perguruan tinggi negeri dan swasta di Indonesia memberikan konsekuensi semakin tingginya tingkat kompetisi lulusan. Oleh sebab itu setiap perguruan tinggi dituntut untuk melakukan berbagai strategi peningkatan mutu lulusan/alumni agar dapat bersaing dengan lulusan perguruan tinggi lain. Jaminan kebermutuan harus meliputi aspek proses, hasil, dan sumber pendukung (Kartadinata 2010).

Tracer study menjadi strategi awal untuk peningkatan mutu lulusan/alumni melalui perbaikan mutu pendidikan di perguruan tinggi. Tracer study merupakan kegiatan penelusuran alumni dengan tujuan untuk mengetahui masa transisi dari dunia kampus menuju dunia kerja (hhtps://karir.itb.ac.id diakses tanggal $21 \mathrm{Mei}$ 2015), serta untuk mengetahui tingkat keterterimaan alumni di masyarakat/di dunia kerja (Arwildayanto 2012). Melalui tracer study, perguruan tinggi akan memperoleh informasi tentang berbagai hal menyangkut alumni, seperti: masa tunggu lulusan, bidang kerja yang ditekuni, serta tanggapan masyarakat pengguna terhadap alumni.

Hasil tracer study dapat digunakan untuk penyempurnaan dan peningkatan mutu perguruan tinggi melalui:

a. Penyempurnaan kurikulum

Kurikulum merupakan salah satu komponen penting dalam sistem pendidikan di perguruan tinggi, di samping komponen lainnya seperti mahasiswa, dan 
tenaga kependidikan lainnya, serta fasilitas. Sejumlah pakar kurikulum berpendapat bahwa jantung pendidikan berada pada kurikulum.Baik buruknya hasil pendidikan ditentukan oleh kurikulum, apakah mampu membangun kesadaran kritis peserta didik ataukah tidak (Yamin 2012). Selanjutnya Yamin (Yamin 2012) mengutip pendapat Prof. Dr. S. Nasution, M.A, yang mengatakan bahwa apapun yang akan dicapai oleh lembaga pendidikan ditentukan oleh kurikulum. Jadi barang siapa yang menguasai kurikulum maka ia memegang peranan penting dalam mengatur nasib bangsa dan negara ke depannya. Kurikulum menjadi vital bagi perkembangan bangsa. Kurikulum mempunyai kedudukan sentral dalam seluruh proses pendidikan. Kurikulum mengarahkan segala bentuk aktivitas pendidikan demi tercapainya tujuan-tujuan pendidikan. Kurikulum merupakan suatu rencana pendidikan yang memberikan pedoman dan pegangan tentang jenis, lingkup, dan urutan isi serta proses pendidikan Kurikulum perguruan tinggi harus dapat menjawab kebutuhan masyarakat atau pengguna lulusan. Oleh sebab itu kurikulum perguruan tinggi perlu disesuaikan dengan perkembangan yang terjadi di masyarakat, khususnya kebutuhan pengguna lulusan. Hasil tracer study akan memberikan informasi yang menjadi masukan bagi perguruan tinggi untuk menyempurnakan kurikulum agar sesuai dengan kebutuhan masyarakat atau pengguna lulusan.

b. Penyempurnaan proses pembelajaran

Selain dapat digunakan untuk penyempurnaan kurikulum, hasil tracer study juga dapat dijadikan sebagai masukan untuk menyempurnakan proses pembelajaran diperguruan tinggi. Penyempurnaan penggunaan metode perkuliahan, pengembangan materi perkuliahan, perbaikan penyelenggaraan evaluasi proses dan hasil belajar seharusnya menjadi tindaklanjut dari hasil tracer study. Kesulitan alumni dalam menampilkan kinerja yang profesional di tempat kerja atau di masyarakat dapat saja terjadi karena proses pembelajaran yang dialaminya selama perkuliahan tidak memberikan kesempatan untuk mengembangkan potensinya secara maksimal serta tidak membekalinya menjadi lulusan yang profesional. Mahasiswa yang selama belajar di perguruan tinggi terjebak dalam kelas-kelas atau ruang-ruang belajar yang kaku akan menjadi lulusan yang dikhawatirkan akan mengulangi pengalaman yang telah dilaluinya itu ketika bertugas di tempat kerja atau dalam kehidupannya di lingkungan masyarakat.

c. Peningkatan kualitas pelayanan kepada mahasiswa dalam kegiatan akademik dan non akademik

Pelayanan yang diperoleh mahasiswa selama proses belajar akan mempengaruhi kualitas hasil belajar yang diperoleh serta kualitas pribadinya secara menyeluruh. Pelayanan akademik melalui proses perkuliahan dan kegiatan akademik lainnya akan membekali mahasiswa dengan berbagai kompetensi yang akan menjadikannya sebagai lulusan yang profesional. Demikian pula halnya dengan pelayanan non akademik seperti keterampilan soft skill, pembinaan karakter, pengembangan jiwa wirausaha akan membentuk lulusan yang memiliki integritas pribadi. Informasi yang diperoleh dari tracer study dapat menjadi masukan untuk perbaikan kualitas pelayanan kepada mahasiswa.

d. Peningkatan manajemen program studi Informasi tentang keterterimaan lulusan/alumni di dunia kerja yang diperoleh melalui tracer study sangat penting dalam rangka perbaikan ataupun penyempurnaan manajemen program studi. Hal ini antara lain sangat terkait dengan penyusunan rencana strategis dan rencana kerja program studi serta implementasinya. Pengembangan berbagai program untuk peningkatan potensi mahasiswa, serta implementasi program tersebut akan sangat efektif jika dapat membentuk lulusan menjadi terterima di dunia kerja.

Di samping dapat digunakan untuk perbaian dan peningkatan mutu pendidikan tinggi, hasil tracer study juga dapat digunakan oleh pihak eksternal dalam hal ini pemerintah terkait dengan pengambilan keputusan di bidang pendidikan itu sendiri dan bidang ketenaga kerjaan. Hasil tracer study dapat digunakan untuk kebijakan dalam hal penganggaran/dana pendidikan, fasilitas pendidikan serta tenaga pendidikan dan kependidikan. Demikian pula halnya di bidang ketenaga kerjaan, hasil tracer study akan memberikan informasi terkait dengan jumlah tenaga kerja yang tersedia, bidangbidang pekerjaan yang perlu dikembangkan, penempatan tenaga kerja, program-program peningkatan keterampilan tenaga kerja, termasuk jumlah pengangguran terdidik maupun tidak terdidik.

Hasil pendidikan dalam hal ini lulusan merupakan indikator efektivitas dan efisiensi proses pendidikan dalam sistem pendidikan. Dari hasil pendidikan, sistem pendidikan memperoleh umpan balik terhadap cara kerja dan proses pendidikan yang sudah berjalan. Umpan balik tersebut digunakan oleh sistem pendidikan sebagai masukan untuk memperbaiki dan meningkatkan mutu proses pendidikannya (Pannen \& Malati 1994). Informasi tentang hasil pendidikan dimaksud dapat diperoleh melalui tracer study yang dilaksanakan oleh perguruan tinggi.

\section{Existensi Program Studi Bimbingan dan Konseling}

Program studi Bimbingan dan Konseling merupakan salah satu program studi di lingkungan Fakultas Ilmu Pendidikan Universitas Negeri Gorontalo berdiri bersamaan dengan pendirian Junior College Fakultas Keguruan dan Ilmu Pendidikan (FKIP) UNSULLUTENG pada tahun 1963 dengan nama program studi Bimbingan dan Penyuluhan. Program studi ini menerima mahasiswa sejak dibuka tahun 1963 sampai dengan masa pashing-out pertama tahun 1972-1975. Sesudah pashing-out pertama, pada tahun 1975 program studi menerima lagi mahasiswa baru sampai dengan masa pashing-out kedua tahun 1986. Dari tahun 1963 sampai dengan tahun 1975 program yang dibuka pada program studi ini terbatas pada program Sarjana Muda. Mulai 
tahun 1979 dengan dikeluarkannya Keputusan Menteri Pendidikan dan Kebudayaan Nomor: 0124/4/1979, yang mengatur pembaharuan jenjang dan jenis program, maka program studi ini membuka program Strata satu (S1) dan tidak membuka lagi program Sarjana Muda.

Sejak IKIP Negeri Manado Cabang Gorontalo beralih status menjadi FKIP UNSRAT di Gorontalo tahun 1982 dengan Kepres RI nomor 70 tahun 1982 yang berlaku sejak tanggal 7 September 1982, program studi Bimbingan dan Penyuluhan (BP) berubah nama menjadi program studi Bimbingan dan Konseling (BK). Perubahan nama ini tidak membawa pengaruh yang prinsipil terhadap kurikulum prodi. Setelah pashing-out kedua tahun 1986 program studi Bimbingan dan Konseling tidak menerima mahasiswa reguler sampai dengan tahun 2006. Atas persetujuan Dirjen Dikti, pimpinan perguruan tinggi pada waktu itu mengambil kebijakan untuk menerima mahasiswa penyetaraan mulai tahun 1987. Mahasiswa yang diterima hanya terbatas pada mereka yang berijazah Sarjana Muda Bimbingan dan Penyuluhan.

Atas perjuangan DPP-IPBI (Dewan Pimpinan Pusat Ikatan Petugas Bimbingan Indonesia), kini disebut ABKIN (Asosiasi Bimbingan dan Konseling Indonesia) agar program studi Bimbingan dan Konseling di semua LPTK yang mengalami pashing-out dapat diizinkan oleh Dikti menerima mahasiswa baru, maka keluarlah surat izin Dirjen Dikti nomor: 204/DT/99, tanggal 6 Agustus 1999 yang memperkenankan semua program studi Bimbingan dan Konseling di LPTK dapat menerima mahasiswa baru dengan catatan bahwa yang menjadi peserta didik adalah guru/Pegawai Negeri Sipil. Berdasarkan surat izin tersebut maka program studi Bimbingan dan Konseling mulai tahun 1999/2000 telah menerima mahasiswa baru. Mahasiswa yang diterima adalah mereka yang berijazah Sarjana Muda, PGSLP/PGSLA, Diploma III, Diploma II, Diploma I dan lulusan SLTA. Selanjutnya sejak tahun akademik 2007/2008 telah menerima mahasiswa reguler. Dokumen resmi terakhir yang menunjukan eksistensi Program Studi Bimbingan dan Konseling Universitas Negeri Gorontalo adalah Surat Keputusan Direktorat JenderalPendidikan Tinggi Departemen Pendidikan Nasional Republik Indonesia, Nomor: 4363/D/T/K-N/2010 tentang Perpanjangan Ijin Program Studi Bimbingan dan Konseling Jenjang S-1 di Universitas negeri Gorontalo, tanggal 8 November 2010.

Perjalanan panjang program studi ini telah menghasilkan sejumlah alumni yang tersebar di berbagai daerah di Indonesia. Terkait dengan tracer study, program studi ini sejak dibuka telah sekali melaksanakan tracer study pada tahun 2014 namun masih sangat terbatas dari segi jumlah maupun daerah tugas alumni, yakni hanya menjangkau sekitar $10 \%$ alumni yang terdapat di provinsi Gorontalo. Jumlah lulusan program studi Bimbingan dan Konseling yang berstatus sejak tahun akademik 2007/2008 sampai tahun akademik 2013/2014 dapat digambarkan dalam tabel 1 berikut:

Tabel 1 Lulusan/Alumni Program Studi Bimbingan dan Konseling

\begin{tabular}{lcc}
\hline No. & Angkatan & Jumlah \\
\hline 1. & $2007 / 2008$ & 30 \\
2. & $2008 / 2009$ & 74 \\
3. & $2009 / 2010$ & 90 \\
4. & $2010 / 2011$ & 72 \\
5. & $2011 / 2012$ & 111 \\
6. & $2012 / 2013$ & 113 \\
7. & $2013 / 2014$ & 93 \\
\hline & Jumlah & $\mathbf{5 8 3}$ \\
\hline
\end{tabular}

Dari jumlah 583 lulusan tersebut, $10 \%$ (175 orang) di antaranya telah berstatus Pegawai Negeri Sipil (PNS) dan non PNS (reguler) berjumlah 408 orang. Data ini menunjukkan pentingnya dilakukan tracer study untuk memperoleh informasi tentang lulusan/alumni.

\section{METODE}

Penelitian ini menggunakan metode penelitian deskriptif kuantitatif untuk memperoleh informasi tentang lulusan/alumni program studi Bimbingan dan Konseling Universitas Negeri Gorontalo. Indikator penelitian meliputi: (a) rata-rata masa tunggu lulusan/alumni, (b) jenis pekerjaan yang ditekuni lulusan/alumni, dan (c) tanggapan pengguna terhadap kinerja lulusan/alumni.

Anggota populasi adalah seluruh lulusan/alumni program studi Bimbingan dan Konseling Universitas Negeri Gorontalolulusan tahun akademik 2007/2008 tahun akademik 2013/2014 yang berjumlah 408 orang. Angota sampel ditetapkan 58\% dari jumlah anggota populasi yakni sejumlah 238 orang. Penentuan anggota sampel menggunakan sampel wilayah (cluster sampling).Wilayah sampel penelitian meliputi daerah provinsi Gorontalo, yakni: Kota Gorontalo, Kabupaten Gorontalo, Kabupaten Bone Bolango, Kabupaten Gorontalo Utara, Kabupaten Boalemo dan Kabupaten Marisa; serta daerah luar provinsi Gorontalo, yakni: Papua, Ternate, Tidore, Kendari, Muna, Luwuk, ToliToli, Bolaang Mongondow.

Pengumpulan data dilakukan dengan menggunakan instrumen tracer study yang diadaptasi dari instrumen tracer study yang dikembangkan oleh DIKTI, dan instrument yang digunakan di borang akreditasi program studi. Data penelitian dianalisis dengan menggunakan analisis persentase.

\section{HASIL DAN PEMBAHASAN} berikut:

Berdasarkan analisis data diperoleh hasil sebagai

a. Masa tunggu lulusan

Secara umum diperoleh data tentang masa tunggu lulusan sebagai berikut:

Tabel 2. Rata-rata Masa Tunggu Lulusan

\begin{tabular}{clll}
\hline NO & $\begin{array}{c}\text { DAERAH } \\
\text { KABUPATEN/KOTA }\end{array}$ & \multicolumn{2}{c}{$\begin{array}{c}\text { LAMA } \\
\text { MASA } \\
\text { TUNGGU }\end{array}$} \\
\hline 1 & Kota Gorontalo & 3 & Bulan \\
2 & Kabupaten Gorontalo & 3 & Bulan \\
3 & Kabupaten Boalemo & 2 & Bulan \\
4 & Kabupaten Pohuwato & 4 & Bulan \\
& Kabupaten Bone & & \\
5 & Bolango & 4 & Bulan
\end{tabular}




\begin{tabular}{clcc}
\hline NO & $\begin{array}{c}\text { DAERAH } \\
\text { KABUPATEN/KOTA }\end{array}$ & $\begin{array}{c}\text { LAMA } \\
\text { MASA } \\
\text { TUNGGU }\end{array}$ \\
\hline \multirow{2}{*}{6} & $\begin{array}{l}\text { Kabupaten Gorontalo } \\
\text { Utara }\end{array}$ & 3 & Bulan \\
& Kotamubagu-Bolmong- & & \\
7 & Bitung & 3 & Bulan \\
8 & Sulawesi Tengah & 2 & Bulan \\
9 & Maluku-Tidore & 2 & Bulan \\
10 & Papua & 3 & Bulan \\
\hline \multicolumn{2}{c}{ Rata-Rata Masa Tunggu } \\
$\quad$ Lulusan & $\mathbf{3}$ & Bulan \\
\hline
\end{tabular}

Data tabel 2 menunjukkan rata-rata masa tunggu lulusan program studi Bimbingan dan Konseling Universitas Negeri Gorontalo adalah 3 (tiga) bulan. Berikut ini gambaran visualisasi dari lama masa tunggu kerja seperti gambar 1 sebagai berikut:

\section{LAMA MASA TUNGGU}

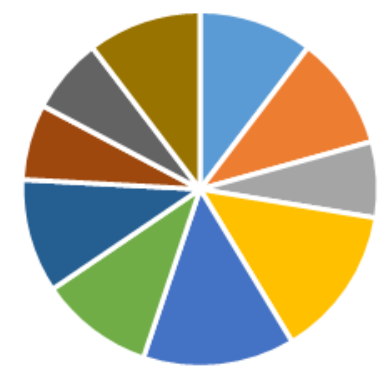

- Kota Gorontalo /3 Bulan

- Kabupaten Gorontalo /3 Bulan

- Kabupaten Boalemo /2 Bulan

- Kabupaten Pohuwato /4 Bulan

- Kabupaten Bone Bolango /4 Bulan

- Kabupaten Gorontalo Utara /3 Bulan

- Kotamubagu-Bolmong-Bitung /3 Bulan

- Sulawesi Tengah /2 Bulan

- Maluku-Tidore /2 Bulan

- Papua /3 Bulan

\section{Gambar 1. Visualiasi Lama Masa Tunggu}

\section{b. Jenis Pekerjaan yang ditekuni}

Berdasarkan hasil pengolahan data, ditemukan jenis pekerjaan lulusan yang dikategorikan dalam 13 (tiga belas) kategori, yakni: (1) Guru Bimbingan dan Konseling (PNS), (2) Guru Bimbingan dan Konseling (Non PNS), (3) Guru Pendidikan Anak Usia Dini (PNS dan Non PNS), (4) Guru Taman Kanak-Kanak (PNS dan Non PNS), (5) Guru Sekolah Dasar (PNS dan Non PNS), (6) Guru Sekolah Luar Biasa (PNS dan Non PNS), (7) Pegawai Instansi Pemerintah non Guru (Non PNS), (8) Pegawai Perusahaan Swasta, (9) Dosen
Program Studi Bimbingan dan Konseling (PNS), (10) Dosen Luar Biasa Program Studi Bimbingan dan Konseling, (11) Wirausaha, (12) Anggota Dewan Perwakilan Rakyat Kabupaten Boalemo, (13) dan lainnya.

Secara umum diperoleh data bahwa pekerjaan dari 238 orang lulusan pada kota/kabupaten di provinsi Gorontalo dan luar Provinsi Gorontalo sebagai berikut: (1) Guru Bimbingan dan Konseling (PNS) sebanyak 27.31\%; (2) Guru Bimbingan dan Konseling (Non PNS) sebanyak 50.00\%; (3) Guru Pendidikan Anak Usia Dini sebanyak 0.84\%; (4) Guru Taman Kanak-Kanak sebanyak 5.04\%; (5) Guru Sekolah Dasar sebanyak 4.20\%; (6) Guru Sekolah Luar Biasa sebanyak 0.42\%; (7) Pegawai Instansi Pemerintah Non Guru sebanyak 2.52\%; (8) Pegawai Perusahaan sebanyak 0.84\%; (9) Dosen sebanyak 1.26\%; (10) Dosen Luar Biasa sebanyak 1.26\%; (11) Wirausaha sebanyak 3.78\%; (12) Anggota DPR sebanyak 0.42\%; (13) dan lain-lain sebanyak $2.10 \%$

c. Tanggapan Pengguna Lulusan

Data pengguna lulusan diperoleh pada 9 dari 10 Kota/Kabupaten yang menjadi sampel dalam penelitian ini, dalam hal ini diperoleh dari 173 responden dari 238 responden Kota/Kabupaten yang diteliti. Hal ini disebabkan beberapa pengguna tidak mengembalikan angket yang dikirim.

Berdasarkan hasil penghitungan, diperoleh ratarata per aspek, yakni: (1) integritas (etika dan moral) = 89.60; (2) keahlian berdasarkan bidang ilmu = (profesionalisme) $=82.92$; $(3)$ bahasa Inggris $=67.89$; (4) penggunaan teknologi informasi $=81.71$; (5) komunikasi $=84.06 ;(6)$ kerjasama $\operatorname{tim}=85.04$; $(7)$ pengembangan diri $=83.83$.

Berdasarkan analisis data diperoleh hasil sebagai berikut: (1) rata-rata masa tunggu lulusan adalah 3 bulan; (2) jenis pekerjaan yang ditekuni lulusan terdiri dari 13 kategori, yakni: (a) Guru Bimbingan dan Konseling (PNS) sebanyak 27.31\%; (b) Guru Bimbingan dan Konseling (Non PNS) sebanyak 50.00\%; (c) Guru Pendidikan Anak Usia Dini sebanyak 0.84\%; (d) Guru Taman Kanak-Kanak sebanyak 5.04\%; (e) Guru Sekolah Dasar sebanyak 4.20\%; (f) Guru Sekolah Luar Biasa sebanyak 0.42\%; (g) Pegawai Instansi Pemerintah Non Guru sebanyak 2.52\%; (h) Pegawai Perusahaan Swasta sebanyak 0.84\%; (i) Dosen sebanyak 1.26\%; (j) Dosen Luar Biasa sebanyak 1.26\%; (k) Wirausaha sebanyak 3.78\%; (1) Anggota DPR sebanyak 0.42\%; (m) dan lain-lain sebanyak $2.10 \%$; (3) tanggapan pengguna per-aspek diperoleh (a) integritas (etika dan moral) = 89.60; (b) keahlian berdasarkan bidang ilmu (profesionalisme) $=82.92 ;(\mathrm{c})$ bahasa Inggris $=67.89 ;(\mathrm{d})$ penggunaan teknologi informasi $=81.71$; (e) komunikasi $=84.06$; (f) kerjasama tim $=85.04$; dan $(\mathrm{g})$ pengembangan diri $=83.83$.

\section{Pembahasan}

Tugas perguruan tinggi tidak hanya menerima calon mahasiswa, melaksanakan proses pendidikan/ pembelajaran, dan meluluskan, namun juga turut bertanggung jawab atas lulusannya. Salah satu aspek 
penilaian keberhasilan perguruan tinggi termasuk program studi adalah kegiatan tindak lanjut terhadap lulusan/alumni. Perguruan tinggi Harvard's School of Business merupakan salah satu perguruan tinggi yang mampu berkompetisi dengan perguruan tinggi lain di Amerika Serikat disebabkan perguruan tinggi ini sangat peduli terhadap alumni (Rowley \& Sherman 2001).

Borang akreditasi program studi mencantumkan salah satu aspek yang dinilai sehubungan dengan akreditasi program studi adalah aspek alumni, yang meliputi: masa tunggu lululusan dalam mendapatkan pekerjaan, dan tanggapan pengguna terhadap alumni. Dari aspek masa tunggu lulusan, hasil penelitian ini menunjukkan masa tunggu lulusan program studi bimbingan dan konseling Universitas Negeri Gorontalo adalah rata-rata 3 bulan. Data ini mengandung makna bahwa: (1) lulusan program studi bimbingan dan konseling Universitas Negeri Gorontalo tidak mengalami masalah dalam memperoleh pekerjaan, termasuk mengurangi pengangguran sebagai masalah nasional, (2) peluang kerja bagi lulusan program studi bimbingan dan konseling Universitas Negeri Gorontalo masih terbuka saat ini. Peluang kerja ini akan terbuka di masa selanjutnya dengan adanya kebijakan pemerintah melalui Permendiknas nomor 111 tahun 2014 tentang Pelayanan Bimbingan dan Konseling di lembaga pendidikan formal (Sekolah Dasar, Sekolah Menengah Pertama, dan Sekolah Menengah Atas). Saat ini penempatan guru Bimbingan dan Konseling baru di Sekolah Menengah Pertama (SMP) dan Sekolah Menengah Atas (SMA). Permendiknas nomor 111 tahun 2014 akan membuka lapangan kerja baru bagi lulusan program studi Bimbingan dan Konseling.

Berkenaan dengan jenis pekerjaan yang ditekuni lulusan, data menunjukkan bahwa lulusan program studi bimbingan dan konseling Universitas Negeri Gorontalo menekuni berbagai jenis pekerjaan, namun terbanyak menekuni pekerjaan sebagai guru Bimbingan dan Konseling baik yang berstatus sebagai Pegawai Negeri Sipil maupun sebagai tenaga honorer. Hasil lain yang diperoleh melalui penelitian ini adalah tentang tanggapan pengguna lulusan. Dari tujuh aspek yang dimintai tanggapan pengguna terhadap lulusan Bimbingan dan Konseling Universitas Negeri Gorontalo, empat aspek (keahlian berdasarkan bidang ilmu/profesionalisme, penggunaan teknologi informasi, komunikasi dan pengembangan diri) dinilai baik, dua aspek lainnya (integritas/etika dan moral, dan kerjasama tim) dinilai sangat baik, dan satu aspek (kemampuan berbahasa Inggris) menunjukkan penilaian kurang baik.

Bagi program studi bimbingan dan konseling data ini akan menjadi motivasi untuk tetap, bahkan lebih memantapkan semangat melaksanakan kegiatan akademik dan non akademik bagi mahasiswa secara berkualitas untuk membantu mahasiswa dapat menyelesaikan studi sesuai target yakni delapan semester (empat tahun) bahkan lebih cepat yakni tujuh semester (3,5 tahun), sebab kurikulum progam studi bimbingan dan konseling memberi peluang bagi mahasiswa yang mampu untuk menyelesaikan studi dalam waktu tujuh semester (3,5 tahun).
Bentuk tindak lanjut lain yang dilakukan oleh program studi bimbingan dan konseling adalah melaksanakan berbagai aktivitas untuk meningkatkan kualitas lulusan dari segi etika moral, profesionalisme, penggunaan teknologi informasi, kemampuan berkomunikasi, kemampuan kerjasama, pengembangan diri, dan kemampuan berbahasa Inggris. Khusus kemampuan berbahasa Inggris perlu mendapat perhatian khusus, mengingat aspek ini memproleh nilai rendah dari para pengguna.

Berdasarkan penelitian ini dapat disimpulkan bahwa kegiatan tracer study merupakan kegiatan penting untuk dilakukan oleh setiap program studi. Melalui tracer study, maka program studi akan memperoleh masukan penting untuk peningkatan kualitas kegiatan akademik dan non akademik dalam rangka mewujudkan lulusan yang berkualitas. Tracer study akan memberikan informasi kepada program studi tentang apa yang dilakukan/dikerjakan oleh lulusan, berapa orang yang sudah atau belum bekerja, di mana mereka bekerja, bagaimana kualitas kerja mereka dan bagaimana harapan pengguna terhadap lulusan. Tracer study menjadi wahana komunikasi dan berbagi antara perguruan tinggi/program studi dengan alumni. Tracer study juga merupakan wujud tanggung jawab perguruan tinggi khususnya program studi terhadap lulusan/alumni.

\section{PENUTUP \\ Simpulan}

Berdasarkan hasil penelitian dapat disimpulkan: (1) Rata-rata masa tunggu untuk bekerja lulusan program studi Bimbingan dan Konseling Universitas Negeri Gorontalo adalah 3 bulan, (2) Jenis pekerjaan yang ditekuni lulusan program studi Bimbingan dan Konseling Universitas Negeri Gorontalo terdiri dari 13 kategori yakni (a) Guru Bimbingan dan Konseling (PNS) sebanyak 27.31\%; (b) Guru Bimbingan dan Konseling (Non PNS) sebanyak 50.00\%; (c) Guru Pendidikan Anak Usia Dini sebanyak 0.84\%; (d) Guru Taman KanakKanak sebanyak 5.04\%; (e) Guru Sekolah Dasar sebanyak 4.20\%; (f) Guru Sekolah Luar Biasa sebanyak 0.42\%; (g) Pegawai Instansi Pemerintah Non Guru sebanyak 2.52\%; (h) Pegawai Perusahaan Swata sebanyak 0.84\%; (i) Dosen sebanyak 1.26\%; (j) Asisten Dosen sebanyak 1.26\%; (k) Wirausaha sebanyak 3.78\%; (1) Anggota Dewan Perwakilan Rakyat Daerah sebanyak $0.42 \%$; (m) dan lain-lain sebanyak $2.10 \%$, (3) Tanggapan pengguna terhadap lulusan program studi Bimbingan dan Konseling Universitas Negeri Gorontalo terhadap delapan aspek, diperoleh: (a) integritas (etika dan moral) = 89.60; (b) keahlian berdasarkan bidang ilmu (profesionalisme $)=82.92 ;(\mathrm{c})$ bahasa Inggris $=67.89 ;(\mathrm{d})$ penggunaan teknologi informasi $=81.71$; (e) komunikasi $=84.06 ;$ (f) kerjasama tim $=85.04 ;(\mathrm{g})$ pengembangan diri $=83.83$

Berdasarkan hasil penelitian disarankan hal-hal sebagai berikut: (1) Bagi lulusan program studi Bimbingan dan Konseling Universitas Negeri Gorontalo diharapkan agar senantiasa melaksanakan tugas secara profesional di bidang kerja masing-masing, baik sebagai 
guru Bimbingan dan Konseling maupun profesi lain, (2) Bagi program studi Bimbingan dan Konseling Universitas Negeri Gorontalo, selain mengembangkan kompetensi mahasiswa dalam bidang bimbingan dan konseling sebaiknya mahasiswa dibekali dengan soft skill seperti kemampuan berbahasa Inggris dan kemampuan penggunaan teknologi informasi yang sangat dibutuhkan dalam kehidupan di era Masyarakat Ekonomi Asean.

\section{DAFTAR PUSTAKA}

Arwildayanto, 2012. Career Development Center Universitas Negeri Gorontalo, Gorontalo: Universitas Negeri Gorontalo.

Kartadinata, S., 2010. Isu-Isu Pendidikan: Antara Harapan dan Kenyataan, Bandung: Pascasarjana Universitas Pendidikan Indonesia.

Pannen \& Malati, 1994. Pendidikan Sebagai Sistem, Jakarta: Dirjen Dikti.

Rowley, D.J. \& Sherman, H., 2001. From Strategy to Change. Implementing the Plan in Higher Education, San Francisco: Joisey-Bass. A Wiley Company.

Yamin, M., 2012. Panduan Manajemen Mutu Kurikulum Pendidikan. Panduan lengkap Tata Kelola Kurikulum Efektif, Yogyakarta: DIVA Press. 